\title{
Disease-limited distributions? Contrasts in the prevalence of avian malaria in shorebird species using marine and freshwater habitats
}

\author{
Luisa Mendes, Theunis Piersma, Miguel Lecoq, Bernard Spaans and Robert E. Ricklefs
}

\begin{abstract}
Mendes, L., Piersma, T., Lecoq, M., Spaans, B. and Ricklefs, R. E. 2005. Diseaselimited distributions? Contrasts in the prevalence of avian malaria in shorebird species using marine and freshwater habitats. - Oikos 109: 396-404.
\end{abstract}

\begin{abstract}
Migratory shorebirds show strong dichotomies in habitat choice during both the breeding and nonbreeding season. Whereas High Arctic breeding species are restricted to coastal marine and saline habitats during the nonbreeding season, more southerly breeding species tend to use freshwater habitats away from coasts. It has been proposed that this co-variation in habitat use is a consequence of a single axis of adaptation to pathogens and parasites, which are hypothesized to be relatively scarce in High Arctic, marine, and saline habitats and relatively common at lower latitudes and in freshwater habitats. Here we examine this contrast by comparing the prevalence of avian malaria infections in shorebirds occupying different habitats. We used a PCR-based assay on 1319 individuals from 31 shorebird species sampled in the Arctic, in temperate Europe and in inland and marine habitats in West Africa. Infections mainly occurred in tropical wetlands, with the shorebirds in freshwater inland habitats having significantly higher prevalence of malaria than birds in marine coastal habitats. Infections were not found in birds migrating through Europe even though conspecifics did show infections in tropical Africa. Adults should resist infection better than juveniles, but showed higher malaria prevalence, suggesting that infection probability increases with cumulative exposure. We argue that exposure to vectors is the main factor explaining the habitat-related differences in malaria prevalence.
\end{abstract}

L. Mendes, T. Piersma and B. Spaans, Dept of Marine Ecology and Evolution, Royal Netherlands Inst. for Sea Research (NIOZ), PO Box 59, NL-1790 AB Den Burg, Texel, the Netherlands (lcgmendes@hotmail.com). - LM also at Depto de Biologia Animal, Faculdade de Ciências da Universidade de Lisboa, Campo Grande, Edificio C3, PT-1749016 Lisboa, Portugal. TP also at Centre for Ecological and Evolutionary Studies (CEES), Univ. of Groningen, PO Box 14, NL-9750 AA Haren, the Netherlands. - M. Lecoq, Sociedade Portuguesa para o Estudo das Aves (SPEA), Rua da Vitória no. 53, 3 esq., PT-1100-618 Lisboa, Portugal. - R. E. Ricklefs, Dept of Biology, Univ. of Missouri-St Louis, MO 63121-4499, USA.

Piersma $(1997,2003)$ has proposed that migration strategies of shorebirds have been shaped by habitat differences in parasite pressure. The basis for this hypothesis is the dichotomy of habitat choice observed in migratory shorebirds, with the species breeding at the highest latitudes being found more in marine and saline habitats during the nonbreeding season, and species breeding at lower latitudes occurring more in freshwater habitats, irrespective of diet and foraging style (Piersma
1997). Marine and saline habitats typically have high salinity, high wind exposure and low vegetation cover, whereas freshwater habitats exhibit lower wind exposure and high vegetation cover. Furthermore, marine habitats harbour molluscs, polychaetes, and crustaceans (Zwarts 1985, 1988, 1997, Piersma et al. 1993, 1997, van de Kam et al. 1999), whereas inland areas are abound with earthworms, plants, and insects. Thus, outside the breeding season, shorebirds restricted to marine 
wetlands tend to eat shellfish, worms and crustaceans (Zwarts 1997, van de Kam et al. 1999) while earthworms, insects and plant seeds predominate in the diets of inland shorebirds (van Rhijn 1991, Piersma et al. 1996, Jukema et al. 2001). However, whereas insects (and especially their larvae) are an important food resource for some inland waders during migration and winter (Piersma et al. 1996), some insect species are also vectors of parasitic diseases such as avian malaria (Cox 1993, Bush et al. 2001). For this reason Piersma (1997) suggested that pathogens and parasites, including vector-borne blood parasites, might be more abundant in freshwater than in marine habitats.

Avian malaria is a disease caused by single-celled parasites in the phylum Apicomplexa that are transmitted between vertebrate hosts by dipteran insects (Cox 1993, Bush et al. 2001). Malaria in humans is caused by four species of Plasmodium related to parasites that cause malaria in other mammals, of which the forms from primates and rodents are well known. Birds and reptiles are infected with related parasites, the best known of which are members of the genus Plasmodium and Haemoproteus (Atkinson and van Riper III 1991). Although these parasites are most readily seen in peripheral blood, where they live mainly within erythrocytes, they initially invade other internal organs, such as the liver, where they may remain for many years (Cox 1993). All have complex life cycles requiring vectors for transmission (Cox 1993, Bush et al. 2001). The most important vectors for avian malaria are Culicoides midges and hippoboscid flies for Haemoproteus and Culex mosquitoes for Plasmodium (Bennett and Combs 1975, Atkinson and van Riper III 1991). Many malaria vectors have a global distribution (Spielman and D'Antonio 2001) and avian malaria is similarly globally distributed. Indeed, malaria parasites have been described in many bird groups and from many geographical areas (Bennett 1993, Bennett et al. 1993, 1994). Nevertheless, some remote areas lacking suitable vectors, or not having been colonized by the parasites, remain free of avian malaria (Warner 1968, Pierce 1981, van Riper III et al. 1986, Earlé and Underhill 1992, Figuerola 1999). Vectors are also thought to be scarce in areas of extreme climate conditions (Earlé and Underhill 1992) and salinity (Figuerola 1999). Host behaviour, such as seasonal movement, also influences parasite prevalence (Moore 2002, Alerstam et al. 2003), with migration distance inversely related to parasite prevalence (in butterflies; Altizer et al. 2000) or intensity of infections (in reindeer; Folstad et al. 1991).

New molecular technologies have improved the detection of vector-borne blood parasites. This has been quite striking with respect to Haemoproteus and Plasmodium (Bensch et al. 2000, Ricklefs and Fallon 2002, Walden- ström et al. 2002, 2004) and Trypanosoma (Sehgal et al. 2001), the prevalence of which has been found to be higher than previously thought (Bensch et al. 2000, Sehgal et al. 2001, Ricklefs and Fallon 2002, Waldenström et al. 2002, 2004), especially in migratory birds (Lajeunesse and Forbes 2001).

In this paper, we capitalize on the new polymerase chain reaction (PCR)-based assays and test the hypothesis that inland wintering shorebirds of freshwater habitats run higher risks of infection by vector-borne blood parasites of the genera Plasmodium and Haemoproteus than similar species using marine habitats. The test is based on an extensive survey of avian malaria infections in shorebirds from different habitat types at different latitudes.

\section{Study area and methods}

Study areas were located along the east Atlantic flyway (Smit and Piersma 1987, van de Kam et al. 1999). Wintering shorebirds were caught during the night with mist nets in coastal marine habitats (Banc d'Arguin National Park, northern Mauritania, $19^{\circ} 21^{\prime}-21^{\circ} 51^{\prime} \mathrm{N}$, $16^{\circ} 00^{\prime}-16^{\circ} 45^{\prime} \mathrm{W}$ in November/December 2002 and western Wadden Sea, the Netherlands, $53^{\circ} 10^{\prime} \mathrm{N}, 5^{\circ} 10^{\prime} \mathrm{E}$ between 1999 and 2002 during spring and autumn migration and also during the winter) and in inland wetlands (Inner Niger Delta, Mali, $15^{\circ} 15^{\prime} \mathrm{N}, 4^{\circ} 15^{\prime} \mathrm{W}$ in February/March 2001, and Diawling National Park, southern Mauritania, $16^{\circ} 10^{\prime} \mathrm{N}, 16^{\circ} 30^{\prime} \mathrm{W}$ in December 2002). We also captured birds during the day using wilsternets (Jukema et al. 2001) in the meadows of the Dutch province of Fryslân $\left(53^{\circ} 4^{\prime} \mathrm{N}, 5^{\circ} 30^{\prime} \mathrm{E}\right)$ in April/ May 2002 and obtained samples from breeding birds captured with clapnets from a high arctic-breeding habitat, Medusa Bay $\left(73^{\circ} 23^{\prime} \mathrm{N} 80^{\circ} 32^{\prime} \mathrm{E}\right)$ in Taymir Peninsula, Russia, during the breeding season of 2002. All birds were ringed, measured, weighed and aged as being in their first year of life or older on the basis of plumage characteristics (Prater et al. 1977). A blood sample of ca $40 \mu \mathrm{l}$ was collected from the brachial vein in a heparinized microhematocrit capillary tube. Blood was transferred to a $1.5 \mathrm{ml}$ tube filed with $96 \%$ ethanol stored at cool temperatures until analysis at the University of Missouri-St. Louis. We screened a total of 1319 individuals from 31 species, of which 15 are restricted to marine habitats and 16 usually occur in inland freshwater habitats (Table 1).

DNA was extracted by solution of dried blood samples in SDS-EDTA lysis buffer followed by alcohol precipitation or a phenol-chloroform protocol (Seutin et al. 1993). The DNA concentration was checked by running the extracted sample in a $1 \%$ agarose gel. Negative samples were re-extracted once. We screened samples for the presence of malaria parasites 
Table 1. Prevalence (number of positives/number sampled) of avian malaria in shorebirds caught along the East Atlantic Flyway. Bird names and order follow Birds of the World (del Hoyo et al. 1996).

\begin{tabular}{|c|c|c|c|c|c|c|c|}
\hline & \multirow{3}{*}{$\frac{\text { Arctic }}{\text { Marine }}$} & \multicolumn{2}{|c|}{ Europe } & \multicolumn{3}{|c|}{ Africa } & \multirow[t]{3}{*}{ Total } \\
\hline & & Marine & Freshwater & Marine & Freshwater & Freshwater & \\
\hline & & $\begin{array}{l}\text { Wadden } \\
\text { Sea }\end{array}$ & Fryslân & $\begin{array}{c}\text { Banc } \\
\text { d'Arguin }\end{array}$ & Diawling & $\begin{array}{c}\text { Inner Niger } \\
\text { Delta }\end{array}$ & \\
\hline $\begin{array}{l}\text { Freshwater species } \\
\text { Oystercatcher Haematopus ostralegus } \\
\text { Black-winged stilt Himantopus himantopus } \\
\text { Senegal thick-knee Burhinus senegalensis } \\
\text { Collared pratincole Glareola pratincola } \\
\text { Spur-winged lapwing Vanellus spinosus } \\
\text { Pacific golden plover Pluvialis fulva } \\
\text { Eurasian golden plover Pluvialis apricaria } \\
\text { Little ringed plover Charadrius dubius } \\
\text { Kittlitz's plover Charadrius pecuarius } \\
\text { Marsh sandpiper Tringa stagnatilis } \\
\text { Green sandpiper Tringa ochropus } \\
\text { Wood sandpiper Tringa glareola } \\
\text { Common sandpiper Actitis hypoleucos } \\
\text { Little stint Calidris minuta } \\
\text { Temminck's stint Calidris temminckii } \\
\text { Ruff Philomachus pugnax } \\
\text { Total }\end{array}$ & $\begin{array}{l}0 / 2 \\
0 / 136 \\
0 / 1 \\
\\
0 / 150\end{array}$ & $0 / 9$ & $\begin{array}{l}0 / 57 \\
0 / 64\end{array}$ & $0 / 17$ & $\begin{array}{l}0 / 1 \\
0 / 5 \\
0 / 6 \\
\\
1 / 7 \\
3 / 5 \\
0 / 2 \\
0 / 1 \\
0 / 12 \\
\\
4 / 84 \\
0 / 1 \\
8 / 124\end{array}$ & $\begin{array}{l}9 / 11 \\
14 / 82 \\
1 / 2 \\
10 / 16 \\
40 / 137\end{array}$ & $\begin{array}{l}0 / 9 \\
0 / 1 \\
0 / 5 \\
2 / 2 \\
1 / 8 \\
0 / 11 \\
0 / 7 \\
2 / 9 \\
5 / 25 \\
0 / 2 \\
0 / 1 \\
9 / 23 \\
0 / 2 \\
18 / 319 \\
1 / 3 \\
10 / 74 \\
48 / 501\end{array}$ \\
\hline $\begin{array}{l}\text { Marine/saline species } \\
\text { Grey plover Pluvialis squatarola } \\
\text { Common ringed plover Charadrius hiaticula } \\
\text { Kentish plover Charadrius alexandrinus } \\
\text { Eurasian dotterel Eudromias morinellus } \\
\text { Jack snipe Lymnocryptes minimus } \\
\text { Bar-tailed godwit Limosa lapponica } \\
\text { Common redshank Tringa totanus } \\
\text { Common greenshank Tringa nebularia } \\
\text { Ruddy turnstone Arenaria interpres } \\
\text { Red knot Calidris canutus } \\
\text { Sanderling Calidris alba } \\
\text { Pectoral sandpiper Calidris melanotus } \\
\text { Curlew sandpiper Calidris ferruginea } \\
\text { Dunlin Calidris alpina } \\
\text { Red-necked phalarope Phalaropus lobatus } \\
\text { Total }\end{array}$ & $\begin{array}{l}0 / 7 \\
0 / 3 \\
0 / 1 \\
0 / 13 \\
0 / 25 \\
0 / 12 \\
0 / 65\end{array}$ & $\begin{array}{l}0 / 3 \\
\\
\\
0 / 1 \\
0 / 56 \\
0 / 3 \\
0 / 1 \\
0 / 28 \\
3 / 367 \\
0 / 2\end{array}$ & 0 & $\begin{array}{l}0 / 9 \\
0 / 19 \\
0 / 16 \\
0 / 27 \\
0 / 42 \\
\\
2 / 28 \\
0 / 34 \\
2 / 181\end{array}$ & $\begin{array}{l}1 / 4 \\
0 / 5 \\
1 / 32\end{array}$ & $0 / 5$ & $\begin{array}{l}0 / 4 \\
0 / 16 \\
0 / 6 \\
0 / 4 \\
0 / 1 \\
0 / 65 \\
0 / 25 \\
0 / 3 \\
0 / 51 \\
3 / 400 \\
0 / 44 \\
0 / 1 \\
3 / 48 \\
0 / 138 \\
0 / 12 \\
6 / 816\end{array}$ \\
\hline Total & $0 / 215$ & $3 / 544$ & $0 / 64$ & $2 / 198$ & $9 / 156$ & $40 / 142$ & $54 / 1319$ \\
\hline
\end{tabular}

by attempting to amplify a 157 base pair section of ribosomal RNA sequence from the $6-\mathrm{kb}$ mitochondrial DNA genome of the malaria parasites (Fallon et al. 2003). This PCR assay can detect infections as weak as $10^{-4}$ to $10^{-5}$ Plasmodium or Haemoproteus parasites per erythrocyte, which is one to two orders of magnitude below the typical detection limit of $10^{-3}$ to $10^{-4}$ parasites per cell by microscopic inspection of blood smears. However, because this PCR protocol is based on peripheral blood DNA, it fails to detect chronic or dormant infections that reside in the liver and other organs, as well as previous malaria infections that can be detected with immunological assays (Atkinson et al. 2001, Jarvi et al. 2002). Samples that were positive were subjected to PCR amplification and sequencing of a ca 300 base pair segment of the mitochondrial cytochrome $b$ gene to identify parasite lineages. Sequencing procedures followed Fallon et al. (2004).
Because our dependent variable is binary: absence of parasites $=0$, presence $=1$, we used general linearized models (GLM) statistics. As we wanted to test which categorical variables were responsible for the observed prevalence, we used a logistic regression (Sokal and Rohlf 1995) from the statistical package Splus 6.1. To understand the overall patterns of parasite prevalence in shorebirds, we first tested for global geographic heterogeneity in observed prevalence. We tested the effect of habitat on parasite prevalence using data from the geographical areas where parasitised birds occurred. Because of the small sample size per habitat for most species, our data were not suitable for a phylogenetically controlled analysis. However, for little stints (Calidris minuta) we were able to make intraspecific comparisons between habitats. Logistic regression was also used to investigate the effect of host age (first year vs older) on parasite prevalence in the tropical freshwater habitats where avian malaria did occur. 


\section{Results}

Of 1319 individuals caught in both inland and marine environments of the Arctic (breeding), Europe (migration and wintering) and Africa (wintering), we detected only 54 that were infected with vector-borne blood parasites of the genera Haemoproteus or Plasmodium. Of the 31 species sampled, only 10 harboured these blood parasites. With the exception of three adult red knots (Calidris canutus) from the Dutch Wadden Sea staging site and two adult curlew sandpipers (Calidris ferruginea) from the Banc d'Arguin, Mauritania, all other infected individuals belonged to species that use inland freshwater habitats (Table 1).

The likelihood of infection with vector-borne blood parasites varied geographically as well as with habitat (Table 2), with African freshwater habitats presenting the highest risk. Although geography and habitat type significantly decreased residual variance in incidence rates, a model that incorporated the interaction between geography and habitat gave a better fit (Table 2). This statistically supports the idea that infection rates are high only in tropical freshwater habitats. We extended this analysis by looking at the prevalence data for Diawling, Mauritania, where both marine and inland shorebird species co-occurred in a freshwater setting. Here, there was no significant difference in parasite prevalence between species typical for coastal and freshwater habitat (GLM: $\mathrm{G}^{2}=0.562, \mathrm{v}=1, \mathrm{p}>0.05$ ). Only for the little stint are our data sufficient to compare prevalence between habitat types for a single species: the increase in malaria prevalence in little stints from Banc d'Arguin (0/17) to Diawling (4/84) and the Inner Niger Delta (14/82) (GLM: $\left.\mathrm{G}^{2}=10.5, \mathrm{v}=2, \mathrm{p}<0.01\right)$, is consistent with the previous analysis. The more inland the habitat, the higher is the prevalence of malaria in little stints and other shorebird species (Table 1). Although there were apparent species differences in prevalence in the African study areas (Table 3), the interaction between habitat and species did not improve the fit of the model. Restricting the analysis to the African freshwater habitats, there was evidence for an age effect on parasite prevalence, with adults (24\% infected) showing a higher prevalence than first-year individuals $(6 \%)$ (GLM: $\mathrm{G}^{2}=12.4, \quad \mathrm{v}=1, \mathrm{p}<0.01$; Table 4). For one species, the ruff (Philomachus pugnax), which was quite heavily infected in the inner Niger Delta, no infected individuals were encountered at a European stopover site. Little stints showed the same pattern, with no infections found in individuals captured in their Arctic breeding area (Table 1).

We were able to sequence only 7 of the 54 positive samples. Low sequencing success can be caused by low concentration of the parasite DNA or by nucleotide substitutions within the priming sites. The parasite lineages that we could sequence were close or even identical to lineages that have previously been described from passerine birds. Phylogenetic placement of the sequences allowed us to assign the parasites to genus: 5 of the infections were of 2 lineages of Haemoproteus and 2 were of different lineages of Plasmodium (Table 5). The cytochrome $b$ sequence of the parasite recovered from one ruff in the inner Niger Delta was identical to Haemoproteus lineage 35 of Ricklefs and Fallon (2002) and two other parasites from the ruff and one from a little stint were very close to this. The other parasite recovered from a little stint differed by only one nucleotide from Haemoproteus lineage 29 of Ricklefs and Fallon (2002). The Plasmodium parasite from a collared pratincole (Glareola pratincola) from Mali grouped with lineages 47 to 55 but was not especially close to any one of them. Finally, a Plasmodium sequence from a little stint captured in Diawling was similar to lineage GRW4 of Perkins and Schall (2002).

\section{Discussion}

\section{Geographical patterns}

The low prevalence of avian malaria in shorebirds revealed by this study - less than $5 \%$ of 1319 individuals - is consistent with values found by previous workers based on microscopic screening of blood smears from western Europe (Pierce 1981) and in the Canadian Arctic (Earlé and Underhill 1992). In addition, we found marked differences in prevalence between habitat types where tropical, inland and freshwater habitats have a higher incidence of infected individuals compared to coastal and northerly areas. This result is consistent with the hypothesis that shorebirds in marine and saline habitats escape exposure to vector-transmitted blood

Table 2. Logistic regression models for the probability of being infected with vector-borne blood parasites along the east Atlantic flyway. Residual variance (D), degrees of freedom $(\mathrm{df})$, difference in variance $\left(\mathrm{G}^{2}\right)$, difference in degrees of freedom $(\mathrm{v})$, and significance of the improvement of the model when compared with the previous model $(\mathrm{P})$.

\begin{tabular}{|c|c|c|c|c|c|c|}
\hline Model & & $\mathrm{D}$ & df & $\mathrm{G}^{2}$ & $\mathrm{v}$ & $\mathrm{P}$ \\
\hline Null & constant probability & 450.5 & 1318 & & & \\
\hline $\begin{array}{l}1 \\
2 \\
3 \\
4 \\
\text { Full }\end{array}$ & $\begin{array}{l}\text { geography } \\
\text { habitat } \\
\text { geography }+ \text { habitat } \\
\text { geography } \times \text { habitat }\end{array}$ & $\begin{array}{c}366.5 \\
349.5 \\
331.6 \\
325.9 \\
0\end{array}$ & $\begin{array}{r}1316 \\
1317 \\
1315 \\
1314 \\
0\end{array}$ & $\begin{array}{r}84 \\
101 \\
17.9 \\
5.7\end{array}$ & $\begin{array}{l}2 \\
1 \\
2 \\
1\end{array}$ & $\begin{array}{l}<0.001 \\
<0.001 \\
<0.001 \\
<0.05\end{array}$ \\
\hline
\end{tabular}


Table 3. Logistic regression models for the probability of being infected with vector-borne blood parasites in West Africa. Residual variance (D), degrees of freedom $(\mathrm{df})$, difference in variance $\left(\mathrm{G}^{2}\right)$, difference in degrees of freedom $(\mathrm{v})$ and significance of the improvement power of the model when compared with the previous $(\mathrm{P})$.

\begin{tabular}{llccccc}
\hline Model & & $\mathrm{D}$ & $\mathrm{df}$ & $\mathrm{G}^{2}$ & $\mathrm{~V}$ & $\mathrm{P}$ \\
\hline Null & constant probability & 292.2 & 447 & & & \\
& & & & 36.8 & 1 & $<0.001$ \\
2 & habitat & 255.4 & 446 & 75.2 & 10 & $<0.001$ \\
3 & species & 216.9 & 437 & 29.6 & 5 & $<0.001$ \\
4 & habitat + species & 187.4 & 432 & - & - & n.s \\
\hline
\end{tabular}

parasites (Piersma 1997, 2003). Similarly, Figuerola (1999) also found lower haematozoan prevalence in birds using saline habitats compared to ones using freshwater habitats. Dowling et al. (2001) found a negative correlation between ectoparasite (feather mite) infestation and environmental salinity in island-dwelling passerines. In another African study, Waldenström et al. (2002) found higher prevalence of blood parasites in passerine species closely associated with wet habitats compared to those species living in drier habitats.

Prevalence of avian malaria is likely associated with vector availability (Bennett and Coombs 1975, Atkinson 1988, Super and van Riper III 1995, Sol et al. 2000), which in turn reflects the availability of suitable breeding conditions for vectors. The main vectors for avian malaria, culicoid mosquitoes and biting midges, depend on stagnant freshwater surfaces to lay their eggs and for larval growth (Cox 1993). Such water surfaces are limited in coastal wetlands. When the transmission of avian malaria depends on particular vectors, the absence of these vectors (even when suitable breeding habitat is present) may prevent the establishment and spread of the disease. In Hawaii, infection of native and introduced species of birds by the introduced Plasmodium relictum depends on the mosquito Culex quinquefasciatus, which is also a non-native species in Hawaii (van Riper III et al. 1986). The introduced Aedes albopictus, which is the vector of Plasmodium fallax in Uganda (Huff et al. 1950), is not a competent vector for P. relictum.

Dependence on particular vectors may also lead to latitudinal variation in seasonal vector availability. Low temperatures and low humidity retard breeding and cause higher mortality rates in mosquitoes, and also stimulate a diet switch from blood to plant sugar to provide energy for overwinter survival (Lindsay et al. 1998, Alto and Juliano 2001, Gary and Foster 2001).

Table 4. Difference between ages and among sites in the prevalence of vector-borne blood parasites in the African freshwater habitats.

\begin{tabular}{|c|c|c|c|c|}
\hline & \multicolumn{2}{|c|}{ Diawling } & \multicolumn{2}{|c|}{ Inner Niger Delta } \\
\hline & Juveniles & Adults & Juveniles & Adults \\
\hline \multicolumn{5}{|l|}{ Freshwater species } \\
\hline Black-winged stilt Himantopus himantopus & & $0 / 1$ & & \\
\hline Senegal thick-knee Burhinus senegalensis & $0 / 2$ & $0 / 3$ & & \\
\hline Collared pratincole Glareola pratincola & & & & $2 / 2$ \\
\hline Spur-winged lapwing Vanellus spinosus & $0 / 1$ & $0 / 4$ & & $1 / 2$ \\
\hline Little ringed plover Charadrius dubius & $1 / 5$ & $0 / 2$ & $0 / 1$ & $1 / 1$ \\
\hline Kittlitz's plover Charadrius pecuarius & $2 / 2$ & $1 / 3$ & $0 / 1$ & $2 / 19$ \\
\hline Marsh sandpiper Tringa stagnatilis & $0 / 1$ & $0 / 1$ & & \\
\hline Green sandpiper Tringa ochropus & $0 / 1$ & & & \\
\hline Wood sandpiper Tringa glareola & $0 / 7$ & $0 / 5$ & $0 / 1$ & $9 / 10$ \\
\hline Temminck's stint Calidris temminckii & & & & $1 / 2$ \\
\hline Little stint Calidris minuta & $0 / 35$ & $4 / 49$ & $4 / 44$ & $10 / 38$ \\
\hline Ruff Philomachus pugnax & $0 / 1$ & & $4 / 6$ & $6 / 10$ \\
\hline Total & $3 / 55$ & $5 / 68$ & $8 / 53$ & $32 / 84$ \\
\hline \multicolumn{5}{|l|}{ Marine/saline species } \\
\hline Grey plover Pluvialis squatarola & $0 / 1$ & & & \\
\hline Common ringed plover Charadrius hiaticula & $0 / 6$ & $0 / 3$ & $0 / 2$ & \\
\hline Kentish plover Charadrius alexandrinus & $0 / 3$ & $0 / 2$ & & \\
\hline Common redshank Tringa totanus & $0 / 3$ & & & \\
\hline Common greenshank Tringa nebularia & $0 / 2$ & & & \\
\hline Red knot Calidris canutus & $0 / 3$ & & & \\
\hline Dunlin Calidris alpina & $0 / 3$ & $0 / 2$ & & \\
\hline Curlew sandpiper Calidris ferruginea & $0 / 3$ & $1 / 1$ & & $0 / 3$ \\
\hline Total & $0 / 24$ & $1 / 8$ & $0 / 2$ & $0 / 3$ \\
\hline Total & $3 / 79$ & $6 / 76$ & $8 / 55$ & $32 / 87$ \\
\hline
\end{tabular}


Table 5. Parasite lineage identification of the sequenced samples from the African freshwater environments.

\begin{tabular}{lllr}
\hline Host species & Sampling site & Genus & $\begin{array}{c}\text { Detected haplotypes } \\
\text { (no. of individuals) }\end{array}$ \\
\hline $\begin{array}{l}\text { Collared pratincole } \\
\text { Glareola pratincola }\end{array}$ & Inner Niger Delta & Plasmodium & $55(1)$ \\
$\begin{array}{l}\text { Little stint } \\
\text { Calidris minuta }\end{array}$ & Diawling & Plasmodium & GRW4 (1) \\
& Inner Niger Delta & Haemoproteus & $35(1)$ \\
Ruff & Inner Niger Delta & Haemoproteus & $29(1)$ \\
Philomachus pugnax & & & $35(3)$ \\
\hline
\end{tabular}

The longer period of suitable temperatures in tropical regions compared with temperate areas may extend the window of opportunity for infective bites by mosquitoes and biting midges. Indeed, in temperate regions most mosquitoes are only active in late summer and early autumn. Thus, when ruffs and others shorebirds are migrating through the freshwater habitats of Europe in spring, vector density would be extremely low and the risk of transmission minimal.

\section{Intraspecific geographical variation in parasite prevalence}

For two species included in this study, the ruff and the little stint, we obtained sufficient samples in temperate and tropical locations to compare parasite prevalence. Both of these species were heavily parasitised in freshwater locations in Africa, but none of the individuals screened was positive during northward migration through the Netherlands or on the Arctic breeding grounds, respectively. Resident populations of small land birds in tropical environments appear to have uniform levels of haematozoan infection throughout the year, in spite of seasonal variation in rainfall (Fallon et al. 2004). The lack of infected ruffs and little stints in the northern parts of their distributions might reflect (1) strong selection against parasitised hosts to undertake the northward spring migration or (2) low survival of those that do.

In addition, the absence of avian malaria in ruffs and little stints in the north may also reflect (3) strong defence against infection, although this seems unlikely in birds that have high prevalence of parasites in winter and are stressed by migration and reproduction in their northern ranges. Clearly, innate defences against malaria infection vary and can be lost in the absence of long term challenges, as on the Hawaii Islands (van Riper III et al. 1986). If coastal shorebirds largely avoided exposure to malaria owing to lack of suitable vectors, then they may have reduced immunity to infection. This may explain why penguins in European and American zoos frequently acquire severe malaria infections (Herman et al. 1968, Fix et al. 1988, Graczyk et al. 1994, 1995,
Takken et al. 2003). The three red knots infected with avian malaria during passage in the Wadden Sea (Table 1) may reflect a low effective natural protection against malaria parasites. Red knots are extreme habitat specialists, with a strong preference for coastal habitats (Piersma 2003); only young, inexperienced individuals during their first southward migration use freshwater habitats in any numbers. Lacking an evolutionary history of exposure to malaria parasites, these birds may not be able to resist infection readily, explaining why the adults still carried infections that were probably established during their first southward migration.

\section{Species and age related differences in prevalence}

In Africa, the likelihood of infection is related to both habitat and species (Table 3). Nevertheless, some species are more likely to be more affected than others. For example in the inner Niger Delta, ruffs and wood sandpipers (Tringa glareola) had much higher infection rates than little stints and Kittlitz's plovers (Charadrius pecuarius). These differences could reflect differences in the immune systems, protective behaviour, or the frequency with which high infection-risk habitats are used. In this context it is noteworthy that, despite juveniles generally having weaker immune response than adults (Lozano and Lank 2003), adults of most species were more heavily infected with parasites than were juveniles. Such an age difference was demonstrated in other studies as well (Dale et al. 1996, Merilä and Andersson 1999, Sol et al. 2000). This could be explained by juveniles not having had as many encounters with potential vectors as adults, or by adults accumulating infections over time, with the subsequent relapse of dormant infections from earlier years.

\section{Parasite composition}

Although one should be careful when interpreting the results on parasite composition, our limited and preliminary data suggest that shorebirds might be more infected with Haemoproteus than Plasmodium. This result is in accordance with studies on songbirds in the 
Lesser Antillean Islands (Fallon et al. 2004) and in Nigeria (Waldenström et al. 2002). All sequenced lineages from shorebirds were similar or identical to lineages described in other birds groups and geographical areas (Ricklefs and Fallon 2002). Remarkably, lineage 35 (Haemoproteus) was first identified in American tanagers (Piranga rubra and Piranga olivaceus) in southern Missouri and closely related lineages have been recovered from North American and West Indian warblers and finches (Ricklefs and Fallon 2002), clearly indicating that some of these parasites are globally distributed. Although limited to the European-African migration route, the Plasmodium lineages show the same trend, as the clade to which lineage 55 belongs has been described form several songbirds in Cameroon (Ricklefs and Fallon 2002) and lineage GRW4 was described from great reed warblers (Acrocephalus arundinaceus) in Sweden (Bensch et al. 2000, Perkins and Schall 2002). That these parasite lineages were recovered from passerines indicates that parasites have the capacity to infect hosts across a broad spectrum of avian orders. However, shorebirds might be incidentally infected by parasites that are endemic at higher prevalence in passerine birds on the wintering grounds in Africa. This might explain the absence of infected individuals at higher latitudes if these parasites could not sustain themselves in shorebirds populations and were cleared from the blood circulation before the northward migration. Whether parasites that were not sequenced in this study belonged to the same lineages or to shorebird-specific lineages can be determined only after sequence is obtained.

\section{Conclusion}

The relative importance of malaria-bearing vectors in geographic and habitat-related patterns of malaria prevalence in shorebirds is supported by the observations that (1) juveniles (with presumably weaker immune defences) have a lower prevalence than adults, (2) little stints exhibit increasing prevalence of avian malaria with distance from the coast, and (3) in one near-coast tropical freshwater habitat where both marine and freshwater specialist shorebirds occur (Diawling) the prevalence of malaria did not differ between the two groups. The absence of an effect of species group (typical habitat) argues against these patterns being related to differences in immunocompetence of coastal and inland species. Thus, our results are consistent with Piersma's (1997) hypothesis that shorebirds with different habitat selection choices, migration strategies and life-history characteristics encounter rather different pathogen and disease regimes (Piersma 2003). We found no evidence that one of these consequences involved adjustment of the level of immune system defences. However, a more complete resolution of this issue awaits experimental studies of immune system responses.

Future studies should focus on the selective pressure that the different parasite lineages have on their host. It is likely that this pressure will be dependent not only on the host life history traits, like habitat selection or migration strategy, but also on parasite characteristics like speed of infection, mode of transmission or virulence. If slow acting parasites like the malaria protozoa are successful in escaping the host immune system, protections against this type of parasites must be achieved by alternative defence mechanisms, like avoidance behaviour.

Acknowledgements - Numerous people were involved in this study. In Mali we had the logistic support of Wetlands International, Bakari Kone, Jan van der Kamp and Leo Zwarts, and counted on the field assistance of Frank Engelen, Mori Dialo and Bouba Fofana. In Fryslân, Joop Jukema and Catharinus Monkel caught the birds. At Medusa Bay, Ingrid Tulp and Hans Schekkerman collected the blood samples. In Mauritania, we had the logistic support of the Parc National du Banc d'Arguin (António Araújo and Jean Worms) and of the Parc National du Diawling (Stephan Boujou). In the field, Jeroen Reneerkens, Casper Kraan, Petra Dieker, Carlos Santos, Manuela Nunes, Martin Poot, Achmed Boubout, Mamadu, Mulu, Foussey Traoré and Achmed Chorfa were of crucial help. Anneke Bol and Bethany Swanson assisted with the PCR assay. We also thank Staffan Bensch, Jonas Waldenström, Pieternella Luttikhuizen, Ben Abbas, Libing Zhang, Irene Tieleman, Sylvia Fallon, and Sebastian Holmes for suggestions and discussions that improved the assay, and Willem Takken for discussions about malaria parasites and their vectors. Jaap van der Meer helped with the statistical analysis. Comments by Martin Poot and Irene Tieleman improved the manuscript. We were supported by BD/19939/99 grant from Fundação para a Ciência e Tecnologia-Portugal to LM, a PIONIER-grant of the Netherlands Organisation for Scientific Research (NWO) to TP, and U.S. National Science Foundation (NSF) grant DEB0089226 to RER.

\section{References}

Alerstam, T., Hedenström, A. and Åkesson, S. 2003. Longdistance migration: evolution and determinants. - Oikos 103: $247-260$.

Altizer, S., Oberhauser, K. and Brower, L. 2000. Associations between host migration and the prevalence of a protozoan parasite in natural populations of adult monarch butterflies. - Ecol. Monogr. 25: 125-139.

Alto, B. and Juliano, S. A. 2001. Temperature effects on the dynamics of Aedes albopictus (Diptera: Culicidae) populations in the laboratory. - J. Med. Entomol. 38: 548-556.

Atkinson, C. T. 1988. Epizootiology of Haemoproteus meleagridis (Protozoa: Haemosporina) in Florida: potential vectors and prevalence in naturally infected Culicoides (Diptera: Ceratopogonidae). - J. Med. Entomol. 25: 39-44.

Atkinson, C. T. and van Riper III, C. 1991. Pathogenicity and epizootiology of avian haematozoa: Plasmodium, Leucocytozoon, and Haemoproteus. - In: Loye, J. E. and Zuk, M. (eds), Bird-parasite interactions. Oxford Univ. Press, pp. $19-48$.

Atkinson, C. T., Dusek, R. J. and Lease, J. K. 2001. Serological responses and immunity to superinfection with avian malaria in experimentally-infected Hawaii Amakihi. - Wildlife Dis. 37: 20-27. 
Bennett, G. F. 1993. Phylogenetic distribution and possible evolution of the avian species of the Haemoproteidae. - Syst. Parasitol. 26: 39-44.

Bennett, G. F. and Coombs, R. F. 1975. Ornithophilic vectors of avian hematozoa in insular Newfoundland. - Can. J. Zool. 53: $1241-1246$.

Bennett, G. F., Bishop, M. A. and Peirce, M. A. 1993. Checklist of the avian species of Plasmodium Marchiafava and Celli, 1885 (Apicomplexa) and their distribution by avian family and Wallacean life zones. - Syst. Parasitol. 26: 171179.

Bennett, G. F., Peirce, M. A. and Earlé, R. A. 1994. An annotated checklist of the valid avian species of Haemoproteus, Leucocytozoon (Apicomplexa, Haemosporida) and Hepatozoon (Apicomplexa, Haemogregarinidae). - Syst. Parasitol. 29: 61-73.

Bensch, S., Stjernman, M., Hasselquist, D. et al. 2000. Host specificity in avian blood parasites: a study of Plasmodium and Haemoproteus mitochondrial DNA amplified from birds. - Proc. R. Soc. Lond. B. 267: 1583-1589.

Bush, A., Fernandez, J., Esch, G. et al. 2001. Parasitism: the diversity and ecology of animal parasites. - Cambridge Univ. Press.

Cox, F. E. G. 1993. Modern parasitology. - Blackwell Science.

Dale, S., Kruszewicz, A. and Slagsvold, T. 1996. Effects of blood parasites on sexual and natural selection in the pied flycatcher. - J. Zool. 238: 373-393.

del Hoyo, J., Elliott, A. and Sargatal, J. (eds). 1996. Handbook of the birds of the world. Vol 3. Hoatzins to Auks. - Lynx Edicions, Barcelona.

Dowling, K., Richardson, D. S., Blaakmeer, K. et al. 2001. Feather mite loads influenced by salt exposure, age and reproductive stage in the Seychelles warbler Acrocephalus sechellensis. - J. Avian Biol. 32: 364-369.

Earlé, R. A. and Underhill, L. G. 1992. Absence of haematozoa in some Charadriformes breeding in the Taimyr Peninsula, Russia. - Ardea 81: 21-24.

Fallon, S. M., Ricklefs, R. E., Swanson, B. L. et al. 2003. Detecting avian malaria: an improved PCR diagnostic. - J. Parasitol. 89: 1044-1047.

Fallon, S. M., Ricklefs, R. E., Latta, S. et al. 2004. Temporal stability of insular avian malarial parasite communities. - Proc. R. Soc. Lond. B. 271: 493-500.

Figuerola, J. 1999. Effects of salinity on rates of infestation of waterbirds by haematozoa. - Ecography 22: 681-685.

Fix, A. S., Waterhouse, C., Greiner, E. C. et al. 1988. Plasmodium relictum as a cause of avian malaria in wildcaught Magellanic Penguins (Spheniscus magellanicus). - J. Wildlife Dis. 24: 610-619.

Folstad, I., Nilsen, A. C., Halvorsen, O. et al. 1991. Parasite avoidance - the cause of post-calving migrations in Rangifer. - Can. J. Zool. 69: 2423-2429.

Gary, Jr., R. E. and Foster, W. A. 2001. Effects of available sugar on the reproductive fitness and vectorial capacity of the malaria vector Anopheles gambiae (Diptera: Culicidae). - J. Med. Entomol. 38: 22-28.

Graczyk, T. K., Brossy, J. J., Plös, A. et al. 1995. Avian malaria seroprevalence in Jackass penguins (Spheniscus demersus) in South Africa. - J. Parasitol. 81: 703-707.

Graczyk, T. K., Cranfield, M. R., Skjoldager, M. L. et al. 1994. An ELISA for detecting anti-Plasmodium spp. antibodies in African black-footed penguins (Spheniscus demersus). - J. Parasitol. 80: 60-66.

Herman, C. M., Kocan, R. M., Snyder, E. L. et al. 1968. Plasmodium elongatum from a penguin. - Wildlife Dis. 4: 132.

Huff, C. G., Marshbank, D. F., Saroff, A. H. et al. 1950. Experimental infections with Plasmodium fallax isolated from the Uganda tufted guinea fowl Numida meleagris major Hartlaub. - J. Nat. Malaria Soc. 19: 307-319.

Jarvi, S. I., Schultz, J. J. and Atkinson, C. T. 2002. PCR diagnosis understimate the prevalence of avian malaria
(Plasmodium relictum) in experimentally-infected passerines. - J. Parasitol. 88: 153-158.

Jukema, J., Piersma, T., Hulscher, J. B. et al. 2001. Golden plovers and wilsternetters: a deeply rooted fascination with migrating birds. - Fryske Akademy, Ljouwert/KNNV Uitgeverij, Utrecht.

Lajeunesse, M. J. and Forbes, M. R. 2001. Host range and local parasite adaptation. - Proc. R. Soc. Lond. B. 269: 703-710.

Lindsay, S. W., Parson, L. and Thomas, C. J. 1998. Mapping the ranges and the relative abundance of the two principal African malaria vectors, Anopheles gambiae sensu stricto and An. arabiensis, using climate data. - Proc. R. Soc. Lond. B. 265: 847-854.

Lozano, G. A. and Lank, D. B. 2003. Seasonal trade-offs in cellmediated immunosenescence in ruffs (Philomachus pugnax). - Proc. R. Soc. Lond. B. 270: 1203-1208.

Merilä, J. and Andersson, M. 1999. Reproductive effort and success are related to haematozoan infections in blue tits. - Ėcoscience 6: 421-428.

Moore, J. 2002. Parasites and the behaviour of animals. - Oxford Univ. Press.

Perkins, S. L. and Schall, J. J. 2002. A molecular phylogeny of malaria parasites recovered from cytochrome b gene sequences. - J. Parasitol. 88: 972-978.

Pierce, M. A. 1981. Distribution and host-parasite check-list of the haematozoa of birds in western Europe. - J. Nat. Hist. 15: $419-458$.

Piersma, T. 1997. Do global patterns of habitat use and migration strategies co-evolve with relative investments in immunocompetence due to spatial variation in parasite pressure? - Oikos 80: 623-631.

Piersma, T. 2003. "Coastal" versus "inland" shorebird species: interlinked fundamental dichotomies between their life- and demographic histories? - Wader Study Group Bull. 100: 59.

Piersma, T., de Goeij, P. and Tulp, I. 1993. An evaluation of intertidal feeding habitats from a shorebird perspective: towards relevant comparisons between temperate and tropical mudflats. - Neth. J. Sea Res. 31: 503-512.

Piersma, T., van Gils, J. and Wiersma, P. 1996. Family Scolopacidae (sandpipers, snipes and phalaropes). - In: del Hoyo, J., Elliott, A. and Sargatal, J. (eds), Handbook of the birds of the World. Vol. 3. Hoatzin to Auks, Lynx Edicions, Barcelona, pp. 444-533.

Prater, A. J., Marchant, J. H. and Vuorinen, J. 1977. Guide to the identification and ageing of holarctic waders. - BTO Guide, Tring, Herts.

Ricklefs, R. E. and Fallon, S. 2002. Diversification and host switching in avian malaria parasites. - Proc. R. Soc. Lond. B. 269: 885-892.

Sehgal, R. N. M., Jones, H. I. and Smith, T. B. 2001. Host specificity and incidence of Trypanosoma in some African rainforest birds: a molecular approach. - Mol. Ecol. 10: $2319-2327$.

Seutin, G., White, B. J., Ricklefs, R. E. et al. 1993. Genetic divergence among populations of a tropical passerine, the streaked saltator (Saltator albicollis). - Auk 110: 117-126.

Smit, C. J. and Piersma, T. 1987. Numbers, midwinter distribution, and migration of wader populations using the East Atlantic Flyway. - In: Boyd, H. and and. Pirot, J.-Y. (eds), Flyways and reserve networks for water birds. IWRB Spec. Publ. 9, Slimbridge, pp. 24-63.

Spielman, A. and D'Antonio, M. 2001. Midge: the story of man's deadliest foe. - Hyperion, New York.

Sokal, R. R. and Rohlf, F. J. 1995. Biometry. - W. H. Freeman. Sol, D., Jovani, R. and Torres, J. 2000. Geographical variation in blood parasites in feral pigeons: the role of vectors. - Ecography 23: 307-314.

Super, P. E. and van Riper III, C. 1995. A comparison of avian hematozoan epizootiology in two California coastal scrub communities. - J. Wildlife Dis. 31: 447-461. 
Takken, W., Huijben, S., Wijsman, A. et al. 2003. Avian malaria in Rotterdam Zoo. - DWHC Newslett. 2: 3-4.

van de Kam, J., Ens, B., Piersma, T. et al. 1999. Ecologische atlas van de Nederlandse wadvogels. - Schuyt \& Co, Haarlem.

van Rhijn, J. G. 1991. The ruff. Individuality in a gregarious wading bird. - T. \& A.D. Poyser.

van Riper III, C., van Riper, S. G., Goff, M. L. et al. 1986. The epizootiology and ecology significance of malaria in Hawaiian land birds. - Ecol. Monogr. 56: 327-344.

Waldenström, J., Bensch, S., Kiboi, S. et al. 2002. Cross-species infection of blood parasites between resident and migratory songbirds in Africa. - J. Mol. Ecol. 11: 1545-1554.
Waldenström, J., Hasselquist, D., Östman, Ö. et al. 2004. A new nested polymerase chain reaction method very efficient in detecting Plasmodium and Haemoproteus infections from avian blood. - J. Parasitol. 90: 191-194.

Warner, R. E. 1968. The role of introduced diseases in the extinction of the endemic Hawaiian avifauna. - Condor 70: $101-120$.

Zwarts, L. 1985. The winter exploitation of fiddler crabs $U c a$ tangeri by waders in Guinea-Bissau. - Ardea 73: 3-12.

Zwarts, L. 1988. Numbers and distribution of coastal waders in Guinea-Bissau. - Ardea 76: 42-55.

Zwarts, L. 1997. Waders and their estuarine food supplies. - Van zee tot land 60. Lelystad. 